\title{
Thin-layer Chromatographic Analysis of Mycolic Acid and Other Long-chain Components in Whole-organism Methanolysates of Coryneform and Related Taxa
}

\author{
By M. GOODFELLOW AND M. D. COLLINS \\ Department of Microbiology, The University, Newcastle upon Tyne NEI $7 R U$ \\ AND D. E. MINNIKIN \\ Department of Organic Chemistry, The University, Newcastle upon Tyne
}

(Received 3 March 1976)

\begin{abstract}
SUMMARY
Acid methanolysates of strains representing 58 coryneform taxa were examined for mycolic acids and other long-chain constituents by thin-layer chromatography. Mycolic esters were detected in the methanolysates of true corynebacteria but not in those from plant pathogenic bacteria, Corynebacterium haemolyticum, Corynebacterium pyogenes or from representatives of the genera Arthrobacter, Cellulomonas, Curtobacterium, Kurthia or Oerskovia. Thin-layer chromatography of whole-organism methanolysates provides a simple method for distinguishing true corynebacteria from coryneforms which do not contain mycolic acids, and from nocardiae and mycobacteria which produce mycolic acids of different mobility. At present the mycolic esters of true corynebacteria cannot be clearly separated from those of some rhodochrous strains.
\end{abstract}

\section{INTRODUCTION}

Bergey's Manual of Determinative Bacteriology currently includes the genera Arthrobacter, Cellulomonas, Corynebacterium and Kurthia in the coryneform group and lists Brevibacterium and Microbacterium as genera incertae sedis (Rogosa et al., 1974). The composition of the genus Corynebacterium remains unsettled: Jones (1975) would include only C. diphtheriae and closely related animal corynebacteria, whereas Rogosa et al. (1974) still recommend the inclusion of the plant pathogenic corynebacteria. The results of numerical phenetic studies (Bousfield, 1972; Jones, 1975) and non-numerical studies (Keddie, Leask \& Grainger, 1966; Bowie et al., 1972) show that the coryneform bacteria form a heterogeneous group. There is good evidence that chemical markers are of value in the classification and identification of coryneform and related taxa (Cummins, I962; Yamada \& Komagata, 1970; Schleifer \& Kandler, 1972).

Mycolic acids, i.e. long-chain 3-hydroxycarboxylic acids having a long alkyl branch on C-2, are lipid components found only in mycobacteria, nocardiae, rhodochrous strains and some corynebacteria (Etémadi, 1967; Maurice, Vacheron \& Michel, 1971). The mycolic acids from corynebacteria examined to date have a relatively low molecular weight ( 20 to 36 carbon atoms) (Pudles \& Lederer, 1954; Diara \& Pudles, 1959; Etémadi, Gasche \& Sifferlen, I965; Welby-Gieusse, Lanéelle \& Asselineau, 1970; Yano \& Saito, 1972). Mycolic acids of a similar size have been isolated from strains bearing the labels Brevibacterium thiogenitalis (Okazaki et al., I969), Arthrobacter paraffineus (Suzuki et al., 1969) and Mycobacterium lacticolum var. aliphaticum (Krasilnikov et al., 1973). 
Systematic investigations of the mycolic-acid composition of coryneform bacteria have not been performed and it is not known whether these lipids will provide good chemical markers for classification and identification. Analysis by thin-layer chromatography (t.1.c.) of ethanol/diethyl ether ( $\mathrm{I}: \mathrm{I}, \mathrm{V} / \mathrm{v}$ ) extracts of true corynebacteria (Jones, 1975), nocardiae and rhodochrous strains showed that these bacteria contained characteristic lipid components identified as free mycolic acids (Mordarska, Mordarski \& Goodfellow, 1972; Goodfellow, 1973; Goodfellow et al., 1973, 1974; Minnikin, Patel \& Goodfellow, 1974; Alshamaony et al., $\mathrm{I} 976 a, b)$. A more convenient procedure, involving t.l.c. of acid methanolysates of dry bacteria, has been developed for analysing the content of mycolic acid and other long-chain constituents (Minnikin, Alshamaony \& Goodfellow, 1975). We have used this whole-organism methanolysis technique to examine 122 strains representing 58 coryneform taxa.

\section{METHODS}

Cultures. The test strains are listed in Table I. Corynebacterium haemolyticum and C. pyogenes cultures were maintained on brain-heart infusion agar (Oxoid); other strains were maintained on Dorset Egg and Loeffler serum slopes (Cowan, 1974).

Cultivation. Corynebacterium haemolyticum and $C$. pyogenes were grown in brain-heart infusion broth (Oxoid) in stationary culture for 4 days at $37{ }^{\circ} \mathrm{C}$, the animal corynebacteria were grown in shake flasks of nutrient broth (Oxoid) supplemented with $\mathrm{I} \%(\mathrm{w} / \mathrm{v}$ ) Tween 80 for 2 days at $37{ }^{\circ} \mathrm{C}$, and the other were strains grown in shake flasks of nutrient broth for 3 days at $30^{\circ} \mathrm{C}$. Corynebacterium sp. $\mathrm{KD}$ was grown on Mueller-Hinton Agar (Oxoid) supplemented with $0.1 \%(\mathrm{w} / \mathrm{v})$ cysteine.

Cultivated organisms were killed with $\mathrm{I} \%(\mathrm{v} / \mathrm{v})$ formaldehyde, harvested by centrifuging, washed with distilled water and freeze-dried.

Whole-organism methanolysis and thin-layer chromatography. Dried organisms were examined using the acid methanolysis and t.l.c. procedure described by Minnikin et al (1975).

\section{RESULTS AND DISCUSSION}

The patterns obtained by chromatography of methanolysates of coryneform bacteria, and of the reference Nocardia, Mycobacterium and rhodochrous strains, are shown in Fig. I. The identity of spots corresponding to mycolic esters was confirmed by washing the developed chromatogram with a mixture of methanol/water $(5: 2, \mathrm{v} / \mathrm{v})$, which removed all spots except those corresponding to the mycolic esters (Minnikin et al., 1975). The spots on the chromatograms having $R_{F}$ values greater than 0.6 are attributable to the methyl esters of non-hydroxylated long-chain fatty acids. On the basis of the results the strains were clustered into six groups: A, B, C, D, E and F (see Table I, Fig. I).

Mycolic esters were detected in methanolysates of Nocardia, rhodochrous strains, certain Corynebacterium strains and in the single strain of Mycobacterium examined. The extract from Mycobacterium avium (Table I, Group E; Fig. I) gave a multispot pattern in accordance with previous studies (Minnikin et al., I975; Etémadi, 1967); single spots were obtained for the mycolates from the other genera included in Groups A, B, C and $D$. The mycolate from the representative strains of Nocardia (Group D) had a relatively high mobility (Fig. I) in comparison with mycolates from Group C strains, which include an authentic representative of the 'rhodochrous' complex. The esters of the mycolic acids from strains in Group A, which includes type and authentic strains of the genus Corynebacterium, had the lowest mobility (Fig. r). Representatives of C. equi and 


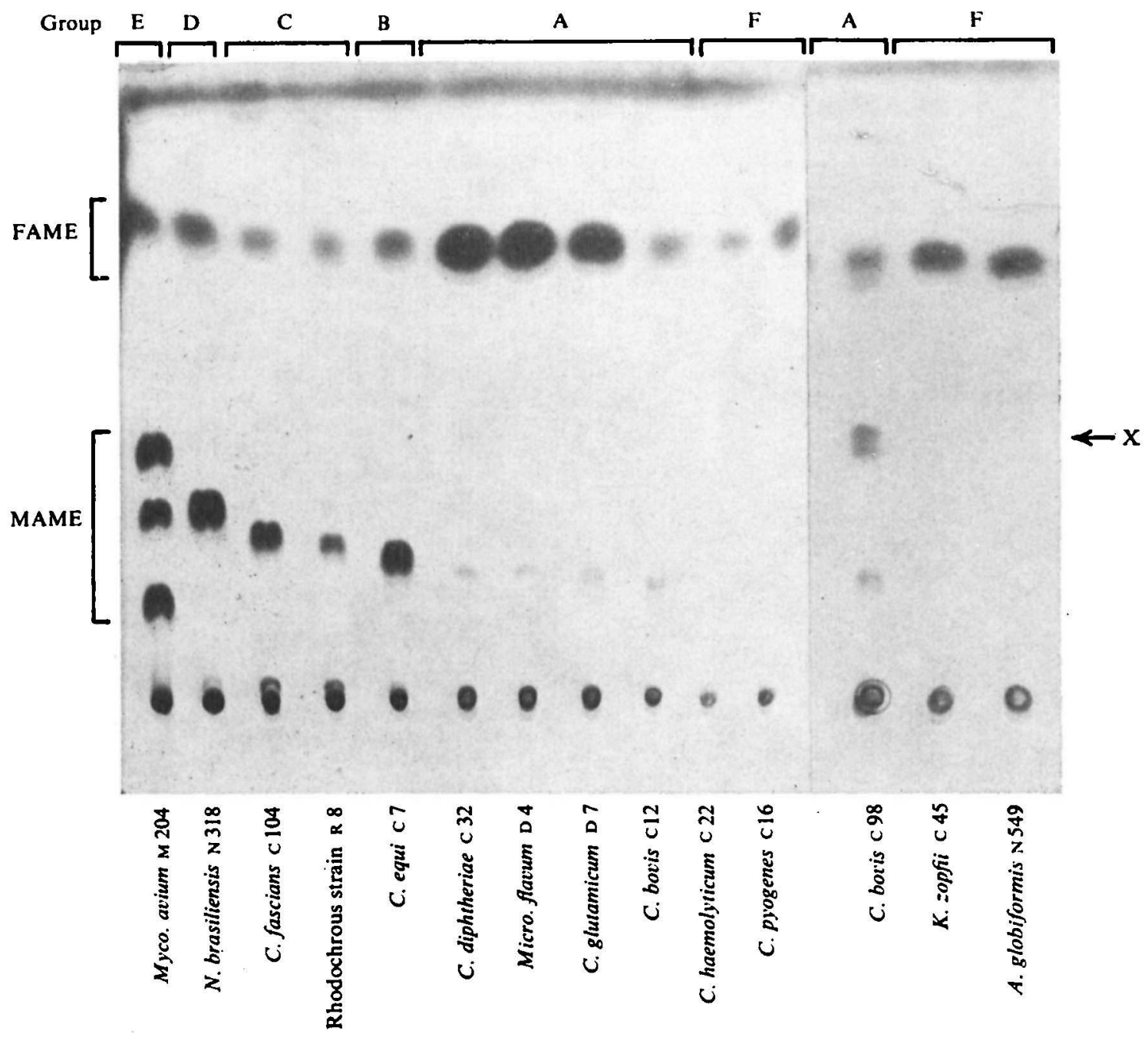

Fig. 1. Thin-layer chromatography of whole-organism methanolysates of selected bacteria. FAME, fatty acid methyl esters; MAME, mycolic acid methyl esters; X, unknown components.

Brevibacterium paraffinolyticum (Group B) gave mycolates whose mobilities were difficult to distinguish clearly from those of representatives of Groups A and C (Fig. I). The spots corresponding to mycolates in extracts of Group A were always relatively low in intensity compared with the spots derived from the simple non-hydroxylated fatty acids (Fig. I); whereas the mycolic ester spots in methanolysates of Groups C and D and the strains of C. equi (Group B) were of much greater relative intensity. Mycolic acids were not found in the other coryneform taxa investigated (Group F).

Methanolysates of four strains included in Group A contained additional components (X) which gave spots on t.l.c. having mobilities intermediate between the mycolic and non-hydroxylated esters, e.g. C. bovis $\mathrm{C} 98$ (Fig. I). Two other strains of C. bovis (C97 and $\mathrm{CIO0}$ ) and a single representative of $C$. xerosis (c33) gave similar patterns, the only difference being that single spots were seen in contrast to the double spot for methanolysates of 
Table I. Grouping of strains based on chromatographic analysis (see Fig. I)

Strain

\section{Group A}

Arthrobacter albidus
A. roseoparaffineus
A. variabilis
Brevibacterium ammoniagenes
B. divaricatum
B. flavum
B. roseum
B. stationis
Corynebacterium bovis

\section{C. diphtheriae}

C. flavidum

C. glutamicum

C. herculis

C. hoagi

C. minutissimum

C. pseudodiphtheriticum

C. pseudotuberculosis

C. renale

C. segmentosum

C. ulcerans

C. xerosis

'Corynebacterium' sp.

Microbacterium flavum

Group B

$B$. paraffinolyticum

C. equi

\section{Group C \\ C. fascians \\ C. hydrocarboclastus}

Rhodochrous strain

Group D

Nocardia brasiliensis

\section{Group E}

Mycobacterium avium
No.

Strain designation/source $\dagger$

\author{
D6 (NCIBI0266) \\ CII 2 (NCIBIO700) \\ D2 (NCIB9455) \\ C80 (NCIB8I43) \\ D3 (NCIB9379) \\ C8I (NCIB9565) \\ C82 (NCIB9564) \\ *C4I (ATCC14403) \\ *CI 2 (NCTC3224); C95, C96, C97
}

(NIRDI689, I 71 8, I928); C98, C99, CIOO, CIOI, CIO2, ClO3 (J. E. Schreeve, Central Veterinary Laboratory, Weybridge, Surrey, DB223/75, DBI 32/75, DB210/75, DB30/75, DB94/75, I 20B) CI 3 (NCTC3985); Cr4 (NCTC3987); *C32 (NCTC3984)

C35 (NCTC764)

D7 (NCIBIO025)

${ }^{*} \mathrm{C} 85$ (NCIB9694)

C24 (NCTCI0673)

D24B (NCTCIO285); *D24 (NCTCIO288)

CI9 (NCTC23I); C73 (D. Jones, Microbial Systematics Unit, University of

Leicester, CIO)

Cl 5 (NCTC3450); H5, H7 (P. Maximescu, Dr I. Cantacuzino Institute, Bucharest, Rumania, 992, 993)

*CI7 (NCTC7448); HI, H2, H3, H4 (R. Yanagawa, Hokkaido University, Sapporo, Japan, 43, 45, 46, 42)

c64 (NCTC934)

CI 8 (NCTC79IO); н6, н8 (P. Maximescu, $896,985)$

C27 (NCTC7238), C33 (NCTC8755)

DIO to DI 8 (I. J. Bousfield, NCIB, SN65, SN66, SN71, SN93, SNI 53, SNI35, SNI 23, SNI49, SNI 30)

*D4 (NCIB8707)

CI 13 (NCIBI I I60)

*C7 (NCTCI62I); C56 (NCTC5649); C57 (NCTC5650); C58 (NCTC4219); DI9, D20, D21, D22, D23 (H. R. Carne, Pathology Department, University of Cambridge, 20343, Jeffcott I, I49, I499, Jeffcott 2)

*C39 (ATCCI 2974); CIO4 (NCPPBI488)

*D8, D9 (K. Komagata, Ajinomoto Co., Kawasaki, Japan, AJI386, AJI379) R8 (ATCC4276)

*N3I8 (ATCCI9296)

M204 (Central Veterinary Laboratory, Weybridge, Surrey, D4) 
Table I. (cont.)

\begin{tabular}{|c|c|c|}
\hline Strain & No. & Strain designation source $\uparrow$ \\
\hline \multicolumn{3}{|l|}{ Group F } \\
\hline A. globiformis & I & *N549 (NCIB8707) \\
\hline A. simplex & $\mathbf{I}$ & $*_{\mathrm{N} 295}(\mathrm{NCIB} 8929)$ \\
\hline Bacterium eurydice & 2 & C49, C50 (D. Jones, C207, C208) \\
\hline Brevibacterium imperiale & I & ${ }^{*} \mathrm{C} 43(\mathrm{ATCC} 8365)$ \\
\hline B. linens & 3 & $\begin{array}{l}\text { C4O (ATCC9I 74); C83 (NCIB9909); } \\
\text { DI (NCIB8546) }\end{array}$ \\
\hline B. sulphureum & $\mathbf{I}$ & C79 (NCIBIO355) \\
\hline Cellulomonas flavigena & I & ${ }^{*} \mathrm{CI}$ I I (NCIB8073) \\
\hline Corynebacterium acnes & I & PI (ATCC692I) \\
\hline C. aquaticum & I & ${ }^{*} \mathrm{C} 84(\mathrm{NCIB} 9460)$ \\
\hline C. barkeri & I & ${ }^{*} \mathrm{C} 8(\mathrm{NCIB} 9658)$ \\
\hline C. betae & $\mathbf{I}$ & C3 (NCPPB363) \\
\hline C. flaccumfaciens & I & C9 (NCPPB559) \\
\hline C. haemolyticum & 2 & ${ }^{*} \mathrm{C} 22$ (NCTC8452); C23 (NCTC9998) \\
\hline C. ilicis & I & ${ }^{*} \mathrm{C} 2$ (ATCCI4264) \\
\hline C. insidiosum & $\mathbf{I}$ & CIO (NCPPB83) \\
\hline C. michiganense & I & C8 (NCPPB 1468) \\
\hline C. nebraskensis & 3 & $\begin{array}{l}{ }^{*} \text { HI I, Hi } 2, \text { HI } 3 \text { (A. Vidaver, University } \\
\text { of Nebraska, Lincoln, Nebraska, U.S.A., } \\
\text { Fur-I, Bennett Goth, } 72 \text { I-s) }\end{array}$ \\
\hline C. okanaganae & I & $\begin{array}{l}\text { *HIo (P. Luthy, Mikrobiologisches } \\
\text { Institut, Zürich, Switzerland, B4405) }\end{array}$ \\
\hline C. poinsettiae & $\mathbf{I}$ & CII (NCPPB844) \\
\hline C. pyogenes & 3 & $\begin{array}{l}\text { *CI6 (NCTC5224); D25 (NCTC6488); } \\
\text { D26 (NCTCI05I3) }\end{array}$ \\
\hline C. rathayi & I & $\mathrm{C} 4$ (NCPPB797) \\
\hline 'Corynebacterium'sp. & I & $\begin{array}{l}\text { HI4 (G. L. Bullock, Kearneysville, West } \\
\text { Virginia, U.S.A., strain KD) }\end{array}$ \\
\hline 'Cheese coryneform bacteria' & 5 & $\begin{array}{l}\text { D24, D25, D26, D27, D28 (M. E. Sharpe, } \\
\text { NIRD, CMDI, CMD3, C4, R6, B4) }\end{array}$ \\
\hline Curtobacterium albidum & I & C92 (NCIBI IO3O) \\
\hline Curtobacterium citreum & $\mathbf{I}$ & *C93 (NCIBI0702) \\
\hline Curtobacterium luteum & I & *C94 (NCIBI IO29) \\
\hline Kurthia zopfii & 5 & $\begin{array}{l}\text { C37, C38, C72, C77 (D. Jones, C5, c6, } \\
\text { C7, C205); *C45 (NCTC404) }\end{array}$ \\
\hline Microbacterium lacticum & 2 & ${ }^{*} \mathrm{C} 90(\mathrm{NCIB} 8540) ; \mathrm{C} 9 \mathrm{I}(\mathrm{NCIB854I})$ \\
\hline Micro. thermosphactum & 5 & $\begin{array}{l}\text { C105, C106, C107, C108, *C109 (D. Jones, } \\
\text { CI, C2, C3, C4, C20) }\end{array}$ \\
\hline Mycobacterium flavum & I & D5 (NCIBIOO7I) \\
\hline Oerskovia turbata & I & ${ }^{*} \mathrm{CI} I O\left(\mathrm{NCIBIO}{ }_{5} 87\right)$ \\
\hline
\end{tabular}

* Type strain.

$\uparrow$ ATCC, American Type Culture Collection, Rockville, Maryland, U.S.A.; NCIB, National Collection of Industrial Bacteria, Aberdeen; NCPPB, National Collection of Plant Pathogenic Bacteria, Harpenden; NCTC, National Collection of Type Cultures, London; NIRD, National Institute for Research in Dairying, Shinfield, Reading; C, D, H, N, P and R, laboratory numbers.

C. bovis $\mathrm{C} 98$ (Fig. I). The nature of these additional components remains to be determined; they can, however, be distinguished from mycolic acids by their mobility on t.l.c. using methanol/water (5:2, v/v) (Minnikin et al., 1975). Long-chain alcohols, such as hentriacontanI6-ol and nocardols found previously in certain strains of nocardioform bacteria (Bordet \& Michel, 1964; 1969; Lanéelle, Asselineau \& Castelnuovo, I965), would be expected to have chromatographic mobilities similar to those of the unknown components.

Our data correlate well with the numerical groupings obtained by Bousfield (1972) and Jones (1975), many strains being common to all three studies. If, as seems advisable, 
the genus Corynebacterium is restricted to the animal corynebacteria and related taxa such as $C$. glutamicum and strains presently labelled Arthrobacter albidus, $A$. roseoparaffineus, $A$. variabilis, Brevibacterium ammoniagenes, B. divaricatum, B. flavum, B. roseum, B. stationis and Microbacterium flavum, then investigations of mycolic-acid composition should be of value in the recognition of such strains. In this connection, a number of strains (Group A, DIO to DI8) isolated from marine fish and provisionally identified as Corynebacterium species (Bousfield, Gunawardana \& Noble, 1976) produced, after methanolysis, mycolic acid esters having the same t.l.c. mobility as those from established species of Corynebacterium. On the other hand, some methanethiol-producing 'cheese coryneform bacteria' (Sharpe, Law \& Phillips, 1976) (Group F, D24 to D28) and the 'Corynebacterium' sp. KD, pathogenic for trout and salmon (Ordal \& Earp, 1956) (Group F, HI4), did not contain mycolic acids.

The finding that strains labelled $C$. fascians and $C$. hydrocarboclastus produced mycolic acid esters with an $R_{F}$ similar to that of many rhodochrous strains supports the case for reclassifying these taxa in the 'rhodochrous' complex (Gordon, 1966; Bousfield, 1972; Komura, Komagata \& Mitsugi, 1973; Jones, 1975). The taxonomic status of C. equi is still debatable for while Bousfield (1972) recovered the type strain in the same phenon as the animal corynebacteria, others have classified it in the 'rhodochrous' complex (Goodfellow et al., 1974; Jones, 1975) and in the present study representatives of $C$. equi were not clearly distinguished from bacteria in either of these groupings. Jones (1975) also recovered $B$. ammoniagenes and $B$. stationis in the same phenon as $C$. equi, but in the present study these brevibacteria gave mycolates whose mobilities were similar to those of strains placed in Group A.

Corynebacterium haemolyticum, C. pyogenes, the remaining plant pathogenic corynebacteria, and saprophytic strains of taxa such as $C$. aquaticum did not contain mycolic acids and can, therefore, be clearly separated from the true corynebacteria (Jones, 1975).

Thin-layer chromatography of whole-organism methanolysates thus provides a simple method for distinguishing true corynebacteria from a host of other coryneforms which do not contain mycolic acids. Analysis of mycolic acid methyl esters by t.l.c. does not, however, presently allow clear distinctions to be made between representatives of true corynebacteria, C. equi, B. paraffinolyticum and the 'rhodochrous' complex.

The authors thank their colleagues who kindly provided bacterial cultures (see Table I), Drs I. J. Bousfield and D. Jones for helpful discussion, and Dr L. Alshamaony for some preliminary studies. One of us (M.D.C.) gratefully acknowledges receipt of a Luccock Scholarship awarded by the Medical Scholarships and Research Committee, Faculty of Medicine, University of Newcastle upon Tyne.

\section{REFERENCES}

Alshamaony, L., Goodfellow, M. \& Minnikin, D. E. (1976a). Free mycolic acids as criteria in the classification of Nocardia and the 'rhodochrous' complex. Journal of General Microbiology 92, I88I99.

Alshamaony, L., Goodfellow, M., Minnikin, D. E. \& Mordarska, H. (1976 b). Free mycolic acids as criteria in the classification of Gordona and the 'rhodochrous' complex. Journal of General Microbiology 92, I83-187.

Bordet, C. \& Michel, G. (1964). Isolément d'un nouvel alcool, le I6-hentriacontanol a partir des lipides de Nocardia brasiliensis. Bulletin de la Société de chimie biologique 46, I IOI-I I 12.

Bordet, C. \& Michel, G. (1969). Structure et biogenèse des lipides à haut poids moleculaire de Nocardia asteroides. Bulletin de la Société de chimie biologique 51, 527-548. 
Bousfield, I. J. (1972). A taxonomic study of some coryneform bacteria. Journal of General Microbiology 7I, $44 \mathrm{I}-455$.

Bousfield, I. J., Gunawardana, Y. \& Noble, S. (I976). Taxonomic study of some coryneform bacteria from marine sources. Proceedings of the Society for General Microbiology 3, 100.

Bowie, I. S., Grigor, M. R., Dunckley, G. G., Loutit, M. W. \& LoutiT, J. S. (1972). The DNA base composition and fatty acid constitution of some Gram-positive pleomorphic soil bacteria. Soil Biology and Biochemistry 4, 397-4I2.

Cowan, S. T. (1974). Manual for the Identification of Medical Bacteria, 2nd edn. Cambridge: Cambridge University Press.

Cummins, C. S. (1962). Chemical composition and antigenic structure of cell walls of Corynebacterium, Mycobacterium, Actinomyces and Arthrobacter. Journal of General Microbiology 28, 35-50.

Diara, A. \& Pudles, J. (I959). Sur les lipides de Corynebacterium ovis. Bulletin de la Société de chimie biologique 4I, 48I-486.

ETÉMADI, A. H. (1967). Corrélations structurales et biogénétiques des acides mycoliques en rapport avec la phylogenèse de quelques generes d'actinomycetales. Bulletin de la Société de chimie biologique 49, $695-706$.

Etémadi, A. H., Gasche, J. \& Sifferlen, J. (1965). Identification d'homologues supérieurs des acides corynomycolique et corynomycolénique dans les lipides de Corynebacterium 506. Bulletin de la Société de chimie biologique 47, 631-638.

Goodfellow, M. (1973). Characterisation of Mycobacterium, Nocardia and Corynebacterium and related taxa. Annales de la Société belge de médecine tropicale 53, 287-298.

Goodfellow, M., Minnikin, D. E., PAtel, P. V. \& Mordarska, H. (1973). Free nocardomycolic acids in the classification of nocardias and strains of the 'rhodochrous' complex. Journal of General Microbiology 74, $185-188$.

Goodfellow, M., Lind, A., Mordarska, H., Pattyn, S. \& Tsukamura, M. (1974). A co-operative numerical analysis of cultures considered to belong to the 'rhodochrous' taxon. Journal of General Microbiology 85, 29I-302.

Gordon, R. E. (1966). Some strains in search of a genus-Corynebacterium, Mycobacterium, Nocardia or what? Journal of General Microbiology 43, 329-343.

JONES, D. (1975). A numerical taxonomic study of coryneform and related bacteria. Journal of General Microbiology 87, 52-96.

Keddie, R. M., Leask, B. G. S. \& Grainger, J. M. (I966). A comparison of coryneform bacteria from soil and herbage: cell wall composition and nutrition. Journal of Applied Bacteriology 29, 1 7-43.

Komura, I., Komagata, K. \& Mitsugi, K. (I973). A comparison of Corynebacterium hydrocarboclastus Jizuka and Komagata 1964 and Nocardia erythropolis (Gray and Thornton) Waksman and Henrici 1948. Journal of General and Applied Microbiology 19, I61-170.

Krasilnikov, N. A., Koronelli, T. V., Rozynov, B. V. \& Kalyuzhnaya, T. V. (1973). Mycolic acids of pigmented paraffin-oxidising mycobacteria. Mikrobiologiya 42, 240-243.

Lanéelle, M. A., Asselineau, J. \& Castelnuovo, G. (1965). Études sur les mycobactéries et les nocardiae. IV. Composition des lipides de Mycobacterium rhodochrous, $M$. pellegrino sp., et de quelques souches de nocardiae. Annales de l'Institut Pasteur 108, 69-82.

Maurice, M. T., Vacheron, M. T. \& Michel, G. (I97I). Isolément d'acides nocardiques de plusieurs espèces de Nocardia. Chemistry and Physics of Lipids 7, 9-18.

Minnikin, D. E., Patel, P. V. \& Goodfellow, M. (1974). Mycolic acids of representative strains of Nocardia and the 'rhodochrous' complex. FEBS Letters 39, 322-324.

Minnikin, D. E., Alshamaony, L. \& Goodfellow, M. (I975). Differentiation of Mycobacterium, Nocardia, and related taxa by thin-layer chromatographic analysis of whole-organism methanolysates. Journal of General Microbiology 88, 200-204.

Mordarska, H., Mordarski, M. \& Goodfellow, M. (1972). Chemotaxonomic characters and classification of some nocardioform bacteria. Journal of General Microbiology 71, 77-86.

Okazaki, H., Sugino, H., Kanzaki, T. \& Fukuda, H. (1969). L-Glutamic acid fermentation. VI. Structure of a sugar lipid produced by Brevibacterium thiogenitalis. Agricultural and Biological Chemistry 33, 764-770.

Ordal, E. J. \& EarP, B. J. (1956). Cultivation and transmission of etiological agent of kidney disease in salmonid fishes. Proceedings of the Society for Experimental Biology and Medicine 92, 85-88.

Pudles, J. \& Lederer, E. (I954). Sur l'isolement et la constitution chimique de l'acide coryno-mycolénique et de deux cétones des lipides du bacille diphtérique. Bulletin de la Société de chimie biologique 36, 759-777.

Rogosa, M., Cummins, C. S., Lelliott, R. A. \& Keddie, R. M. (1974). Bergey's Manual of Determinative Bacteriology, 8th edn, pp. 599-633. Edited by R. E. Buchanan and N. E. Gibbons. Baltimore: Williams and Wilkins.

Schleifer, K. H. \& Kandler, O. (I972). Peptidoglycan types of bacterial cell walls and their taxonomic implications. Bacteriological Reviews 36, 407-477. 
Sharpe, M. E., Law, B. A. \& Phillips, B. A. (1976). Coryneform bacteria producing methane thio Journal of General Microbiology 94, 430-435.

Suzuki, T., TANaka, K., Matsubara, I. \& Kinoshita, S. (1969). Trehalose lipid and $\alpha$-branched- $\beta$-hydroxy fatty acid formed by bacteria grown on n-alkanes. Agricultural and Biological Chemistry 33, I6I91627 .

Welby-Gieusse, M., Lanéelle, M. A. \& Asselineau, J. (1970). Structure des acides corynomycoliques de Corynebacterium hofmanii et leur implication biogénétique. European Journal of Biochemistry 13, I64-167.

Yamada, K. \& Komagata, K. (1970). Taxonomic studies on coryneform bacteria. I. Principal amino-acids in the cell wall and their taxonomic significance. Journal of General and Applied Microbiology 16, IO3-II3.

YANO, I. \& SAITO, K. (1972). Gas chromatographic and mass spectrometric analysis of molecular species of corynomycolic acids from Corynebacterium ulcerans. FEBS Letters 23, 352-356. 